\title{
EFEKTIVITAS METODE MULTISENSORI DALAM MENINGKATKAN KEMAMPUAN MEMULAI MEMBACA PADA ANAK TUNAGRAHITA RINGAN
}

\author{
Muhamad Aba Bahrun Mustofa, Tatik Mukhoyyaroh'1
}

Fakultas Psikologi dan Kesehatan Universitas Islam Negeri Sunan Ampel, Surabaya

\begin{tabular}{|c|c|}
\hline Keywords/Kata kunci & ABSTRACT/ABSTRAK: \\
\hline $\begin{array}{l}\text { mild retardation, } \\
\text { multisensory method, } \\
\text { pre-reading, special } \\
\text { school. }\end{array}$ & $\begin{array}{l}\text { This study aims to test the effectiveness of the multisensory method of early } \\
\text { reading skills in children with mild mental retardation in grade VI at SLB } \\
\text { (Special School) Bina Bangsa, Ngelom, Taman, Sidoarjo. The research } \\
\text { method used in this research is the Single Subject Research (SSR) } \\
\text { experimental method with the ABA design model. The subject in this study } \\
\text { was a grade } 6 \text { student with mental retardation at Special School (SLB) } \\
\text { Bina Bangsa, Ngelom, Taman, Sidoarjo. The data collection technique used } \\
\text { in this study was an initial reading ability test. The data analysis technique } \\
\text { in this research is descriptive statistical data analysis techniques with data } \\
\text { analysis in conditions and between conditions. The results of this study } \\
\text { indicate that the multisensory method is effective in improving early } \\
\text { reading skills in mildly retarded children. }\end{array}$ \\
\hline
\end{tabular}

membaca permulaan, metode multisensori, retardasi ringan, sekolah luar biasa.
Penelitian ini bertujuan untuk menguji efektivitas metode multisensori keterampilan membaca awal pada anak retardasi mental kelas VI di SLB (Sekolah Luar Biasa) Bina Bangsa, Ngelom, Taman, Sidoarjo. Penelitian ini menggunakan pendekatan kuantitatif dengan jenis penelitian eksperimental dan menggunakan desain ABA. Subjek dalam penelitian ini adalah seorang siswa kelas VI Sekolah Luar Biasa (SLB) Bina Bangsa, Ngelom, Taman, Sidoarjo, yang mengalami retardasi mental ringan. Teknik data yang digunakan dalam penelitian ini adalah tes kemampuan membaca awal. Teknik analisis data dalam penelitian ini ialah statistik deskriptif dengan analisis data dalam kondisi dan antar kondisi. Hasil penelitian menunjukkan bahwa metode multisensori efektif dalam meningkatkan keterampilan membaca awal pada anak retardasi ringan.

\footnotetext{
${ }^{1}$ Korespondensi mengenai artikel ini dapat dilakukan melalui email tatikfpk@uinsby.ac.id 
Membaca penting dalam kehidupan sosial, tanpa kemampuan membaca informasi tidak dapat diperoleh (Tarigan, 2008). Meski demikian, tidak semua orang dapat membaca, misalnya anak dengan retardasi mental. Maslim, (2013) menyatakan bahwa anak dengan retardasi mental ringan adalah anak yang memiliki IQ di bawah skor IQ pada anak normal, yaitu antara 50 - 69. Dengan nilai IQ di bawah ratarata tersebut membuat anak retardasi mental ringan mengalami kesulitan yang sangat besar yaitu pada menerima pembelajaran termasuk dalam hal membaca. Hal ini dikarenakan kemampuan membaca sangat erat kaitannya dengan kecerdasan seseorang.

Sejalan dengan pendapat tersebut, Slamet \& Vismaia (2003) menyatakan bahwa anak yang memiliki tingkat konsentrasi IQ rendah 50 dan daya imajinasi yang rendah, sehingga ketika anak retardasi mental dihadapkan pada kalimat-kalimat yang sulit akan sangat sulit untuk dipahami. Namun, mereka yang memiliki skor antara 50 dan 70 akan dapat membaca dengan pembelajaran khusus. Lebih lanjut, Abdurrahman, (2009) mengemukakan bahwa terdapat hal-hal yang abstrak yang sulit dipahami oleh anak retardasi mental ringan, yaitu dalam hal membaca, berhitung, menggunakan simbol dan memahami pelajaran teoritis. Hal itu disebabkan, untuk memikirkan hal-hal yang abstrak harus mempunyai daya imajinasi yang kuat, sedangkan anak retardasi mental ringan tidak memilikinya.

Dalam penelitian Astuti, (2013) disebutkan bahwa penelitian yang dilakukan Annual Report to Congress terdapat 2\% anak usia sekolah dengan retardasi mental, dengan rasio $60 \%$ laki-laki dan $40 \%$ perempuan atau 3:2. Data dari Badan Pusat
Statistik (BPS) pada 2015, dari 235 juta penduduk Indonesia, $0,7 \%$ atau 2,8 juta adalah penyandang disabilitas. Sedangkan populasi retardasi mental menempati tempat terbesar dibandingkan dengan anakanak dengan keterbatasan lainnya. Prevalensi retardasi mental saat ini diperkirakan 1-3\% dari populasi Indonesia, sekitar 6,6 juta orang. Anak retardasi mental ini mengenyam pendidikan formal di Sekolah Luar Biasa (SLB) Negeri dan Sekolah Luar Biasa (SLB) Swasta.

Penelitian yang dilakukan Lestari, (2014) menyebutkan bahwa di negara maju terdapat $10,5 \%$ siswa yang mengalami kesulitan membaca. Salah satu kegagalan siswa adalah karena tidak memiliki kemampuan membaca, padahal kemampuan membaca merupakan salah satu faktor penentu keberhasilan siswa di sekolah. Menurut penelitian, kesulitan belajar secara keseluruhan pada anak usia sekolah memiliki kejadian yang bervariasi. Di negara maju seperti Amerika Serikat dan Eropa, angka kejadian kesulitan belajar kira-kira 10-15\% dari populasi anak sekolah. Angka kejadian anak laki-laki lebih banyak dibandingkan anak perempuan 8:1 (Santosa, 2012). Prevalensi kesulitan belajar juga sangat bervariasi, di Jawa Timur, Jawa Barat, Lampung dan Kalimantan Barat, ditemukan 13,7\% siswa usia SD mengalami kesulitan membaca (Chodijah, 2014).

Berdasarkan studi pendahuluan di SLB Bina Bangsa Ngelom, Taman, Sidoarjo, terdapat anak retardasi mental ringan kelas VI yang sudah terlihat pada tahap awal membaca yaitu kesiapan membaca. Hal ini terlihat dari minat siswa terhadap buku dan dapat memfokuskan perhatiannya pada satu atau dua aspek. Kemampuan membaca yang dimiliki anak tersebut ialah mampu mengenali semua jenis huruf mulai dari "A" hingga "Z" tanpa satu pun huruf terbalik seperti huruf "b" dan "d", "p" dan "q" dan 
dapat dibaca per kata yang mudah dan sering dilihat, namun untuk membaca 2 sampai 4 suku kata digabungkan dan kalimat bacaan sederhana masih mengalami kesulitan. Untuk itu agar kemampuan membaca anak bisa lebih baik lagi, peneliti ingin meningkatkan tahap membaca ke tahap berikutnya yaitu membaca permulaan. Pada tahap membaca pendahuluan ini, anak mulai belajar kosakata, menggabungkan 2 sampai 4 suku kata, dan membaca kalimat sederhana.

Berdasarkan wawancara dengan beberapa guru wali kelas di SLB Bina Bangsa Ngelom, Taman, Sidoarjo, metode belajar mengajar yang diterapkan oleh guru pengajar selama ini menggunakan kartu kata dan buku bacaan. Cara ini masih kurang tepat untuk mendukung kemampuan membaca anak retardasi mental ringan. Hal ini dikarenakan metode pembelajaran pada anak retardasi mental ringan harus berbeda dengan metode pembelajaran yang diterapkan pada anak normal. Oleh karena itu, metode pembelajaran yang diterapkan harus efektif agar anak retardasi mental ringan dapat mencapai pemahaman. Berdasarkan hal tersebut, peneliti tertarik untuk menggunakan metode multisensori guna mengetahui efektivitas metode multisensori dalam meningkatkan kemampuan membaca awal anak retardasi mental ringan.

Berdasarkan informasi yang diuraikan di atas, maka peneliti tertarik untuk melakukan penelitian terkait dengan "Efektivitas Metode Multisensori dalam Meningkatkan Kemampuan Memulai Membaca pada Anak Cacat Ringan". Peneliti mengambil tema penelitian tersebut karena penelitian ini hanya digunakan satu kali dan metode multisensori terbukti efektif dalam meningkatkan kemampuan memulai membaca pada anak retardasi mental.

Perbedaan yang membedakan penelitian ini dengan penelitian sebelumnya adalah subjek penelitian dan lokasi penelitian. Penelitian sebelumnya yang dilakukan oleh Setyawati, (2017) melibatkan subjek retardasi mental ringan di Sekolah Dasar Kelas II di SLB Negeri Semarang, sedangkan dalam penelitian ini anak retardasi mental ringan kelas VI di SLB Bina Bangsa Ngelom, Taman, Sidoarjo.

Dalam perkembangan kognitif anak normal, terdapat perbedaan mendasar antara anak kelas II dan kelas VI SD yaitu bahwa anak kelas II memasuki tahap pra operasional, dimana anak belajar dan mempresentasikan benda dengan gambar dan kata. Tahap kognitif anak kelas II SD berpikir lebih simbolis namun tidak melibatkan pemikiran operasional dan lebih egosentris daripada logis, sedangkan anakanak kelas VI SD memasuki tahap operasional formal. Sementara itu, anak retardasi mental perkembangan kognitifnya memiliki keterbatasan, tergantung tingkat keparahan.

Anak retardasi mental ringan memiliki kemampuan membaca yang rendah. Berdasarkan hasil tersebut, anak retardasi mental seringkali melakukan kesalahan dalam membaca. Kesalahan yang dilakukan oleh anak retardasi mental berakibat pada kesalahan makna dari apa yang mereka baca. Kesalahan tersebut adalah, penghapusan kata, pemotongan yang tidak tepat, dan tidak mengenali bunyi konsonan dan vokal (Setyawati, 2017). Salah satu ciri yang dimiliki oleh keterbelakangan intelektual ringan adalah sulitnya memikirkan sesuatu yang abstrak dan logis. Ketidakmampuan tersebut dapat menghambat penerapan bahan bacaan pada anak retardasi mental sehingga untuk meningkatkan kemampuan membaca sebaiknya guru atau terapis menggunakan metode pembelajaran yang sesuai (Diyah, 2014).

Sebagai upaya meningkatkan kemampuan membaca awal pada anak retardasi mental ringan agar bisa lebih baik, peneliti berasumsi bahwa anak retardasi 
mental ringan membutuhkan bantuan dari berbagai modalitas dan metode pembelajaran khusus guna meningkatkan kemampuan membaca mereka. Salah satu caranya ialah menerapkan metode khusus dan efektif, misalnya metode multisensori. Metode multisensori memiliki beberapa manfaat, diantaranya efektif untuk meningkatkan keterampilan membaca pada siswa penderita disleksia di sekolah dasar. Hasil penelitian yang dilakukan oleh Komalasari, (2013) membuktikan bahwa metode multisensori dapat meningkatkan kemampuan membaca siswa penderita disleksia di sekolah dasar.

Manfaat lain dari metode multisensori ialah dapat digunakan untuk meningkatkan kemampuan membaca pada anak retardasi mental ringan. Hal ini sesuai dengan penelitian yang dilakukan oleh Setyawati, (2017) bahwa metode multisensori efektif dalam meningkatkan kemampuan membaca, dan mulai membaca pada anak retardasi mental kelas II di SLB Negeri Semarang. Selain efektif dalam membantu membaca, manfaat lain dari metode multisensori adalah dapat meningkatkan keterampilan menulis pada anak yang mengalami kesulitan belajar menulis. Hal ini sejalan dengan penelitian yang dilakukan oleh Kusumaningtyas (2015), bahwa metode multisensori efektif dalam meningkatkan keterampilan menulis anak yang mengalami kesulitan belajar menulis kelas III di SD Muhammadiyah Demangan, Yogyakarta.

Selain meningkatkan keterampilan membaca dan menulis pada anak retardasi mental dan anak dengan kesulitan belajar, metode multisensori juga efektif meningkatkan kemampuan membaca peringatan tertulis pada anak tunanetra dengan low vision. Hal tersebut terbukti pada penelitian Pertiwi, (2016), bahwa metode multisensori efektif meningkatkan kemampuan membaca dan menulis permulaan penglihatan pada anak tunanetra kelas I sekolah dasar luar biasa (SDLB) low vision di SLB A Yaketunis, Yogyakarta.

Berdasarkan beberapa bukti penelitian dan manfaat metode multisensori di atas, peneliti memfokuskan penelitian ini pada metode multisensori dalam meningkatkan kemampuan membaca anak retardasi mental ringan karena metode multisensori ini terbukti efektif dalam meningkatkan keterampilan membaca pemula pada anak. Hal itu karena metode multisensori menstimulasi indera anak sehingga sistem saraf anak dapat bereaksi.

\section{METODE PENELITIAN}

Metode penelitian yang digunakan dalam penelitian ini adalah metode eksperimen Single Subject Research (SSR) dengan model desain ABA. Tujuannya ialah untuk mengetahui ada tidaknya hubungan antara variabel independen dengan variabel dependen. Desain ABA merupakan perpanjangan dari desain $A B$ dengan melakukan dua kali pengulangan pengukuran kondisi baseline. Prosedur dasarnya adalah pengukuran pada kondisi baseline (A1) kemudian pada kondisi intervensi (B) dan pengukuran ulang dilakukan pada kondisi baseline (A2) (Sunanto, 2006).

\section{Subjek penelitian}

Subjek dalam penelitian ini adalah anak retardasi mental ringan kelas VI di SLB Bina Bangsa, Ngelom, Taman, Sidoarjo, berjumlah 1 anak yang memiliki kemampuan membaca awal rendah. Kriteria inklusi dalam penelitian ini adalah anak retardasi mental yang tidak bisa membaca di awal, dengan rekomendasi dari wali kelas dan juga dari buku data tes kecerdasan siswa. Untuk memastikan, peneliti juga menggunakan checklist mengenai retardasi mental ringan sebagai dasar yaitu buku 
PPDGJ - III (F70 - F79) dan DSM - V. Selain

memastikan bahwa subjek memiliki kemampuan membaca awal yang buruk, peneliti dibantu oleh wali kelas yang meminta anak untuk melafalkan semua huruf alfabet.

\section{Desain penelitian}

Tampilan desain ABA dapat dilihat pada Gambar dibawah ini:

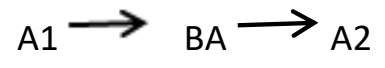

Gambar 1. Desain Penelitian

Informasi:

A-1 (baseline-1) adalah kondisi baseline subjek sebelum pengobatan atau intervensi. Pada fase ini ada 3 sesi dengan waktu yang dibutuhkan (30 menit). Tahapan ini dilakukan hingga data stabil kemudian peneliti menilai subjek dengan meminta subjek mengerjakan 22 soal keterampilan membaca awal.

BA (intervensi) adalah kondisi kemampuan membaca awal subjek saat diberikan perlakuan atau perlakuan berulang menggunakan metode multisensori hingga hasil yang diperoleh stabil. Pada tahap ini subjek diberikan perlakuan mengidentifikasi huruf, suku kata bacaan, dan kalimat sederhana. Perawatan diberikan selama 6 sesi, setiap sesi membutuhkan waktu $2 \times 35$ menit.

A-2 (baseline-2) merupakan pengulangan tahap baseline-1 sebagai bentuk evaluasi bagaimana intervensi yang diberikan dapat mempengaruhi kemampuan membaca awal anak retardasi ringan dengan membandingkan kondisi subjek pada baseline-1 dan baseline- 2 (Setyawati, 2017)

\section{Metode pengumpulan data}

Pengumpulan data dalam penelitian ini menggunakan tes kemampuan membaca pendahuluan yang dilaksanakan pada setiap tahapan. yaitu tahap baseline-1, tahap intervensi, dan tahap baseline-2.

\section{Prosedur Intervensi}

Dalam prosedur intervensi pada penelitian ini terdapat beberapa tahapan, yang pertama adalah Tahap Pra Eksperimen (Baseline Phase-1). Pada tahap ini terdapat 2 tahap yaitu tahap persiapan dan tahap baseline-1. Pada tahap persiapan, peneliti menentukan subjek yang akan ditangani peneliti yaitu anak retardasi mental ringan kelas VI di SLB Bina Bangsa, Ngelom, Taman, Sidoarjo yang pada awalnya memiliki kemampuan membaca yang buruk. Setelah itu mempersiapkan media sebagai alat pendukung dalam pembelajaran dengan metode multisensori yaitu huruf timbul, spidol hitam, kartu surat, nampan, kertas asturo hitam, tepung hunkue, dan kertas HVS putih. Selanjutnya pada fase Baseline-1 dilakukan tes dengan tujuan untuk mengetahui kemampuan membaca mata pelajaran awal. Fase ini dilakukan selama 1 minggu dengan 3 sesi. Peneliti memberikan instruksi dengan membacakan soal kepada subjek untuk mengerjakan soal dan subjek menjawabnya secara lisan. Ada 22 pertanyaan yang diberikan kepada subjek.

Yang kedua adalah fase percobaan atau tahap intervensi. Tahap intervensi dilakukan selama 3 minggu dalam 6 sesi. Tahapan ini bertujuan untuk mengumpulkan data selama masa intervensi yaitu dengan menggunakan metode 
multisensori untuk meningkatkan kemampuan memulai membaca pada anak retardasi ringan. Kegiatan yang dilakukan pada tahap ini adalah pengenalan, yang meliputi: peneliti menyapa, dilanjutkan dengan mengatur posisi duduk subjek supaya benar dan tenang. Kemudian peneliti menyiapkan media dan bahan yang digunakan dalam proses pembelajaran. Peneliti juga menjelaskan tujuan pembelajaran dan materi yang akan disampaikan.

Berikutnya adalah pembelajaran inti. Pada tahap ini peneliti memberikan materi pembelajaran berupa pengenalan huruf yang disusun menjadi kata-kata dan dilanjutkan dengan materi yang lebih kompleks. Kegiatan pembelajaran yang dilakukan dengan menerapkan metode multisensori ini adalah sebagai berikut: materi I yaitu mengenal huruf yang tersusun menjadi kata-kata, yaitu dengan cara, peneliti menunjukkan kartu huruf dan membacakan surat tersebut kepada subjek. Kemudian subjek diminta membaca surat yang telah dibaca oleh peneliti. Peneliti selanjutnya meminta subjek untuk menyentuh huruf timbul dan mengamati huruf tersebut serta memintanya mengeja huruf. Peneliti kemudian menyiapkan nampan untuk diberikan kepada subjek. Peneliti menyusun huruf menjadi kata-kata, kemudian meminta subjek untuk menuliskan kembali kata tersebut pada nampan. Sesi ini diakhiri dengan cara, peneliti mengulang materi yang telah diserahkan dan memberikan pertanyaan pada mata kuliah tentang materi yang telah dipelajari.

Materi II: membaca kosakata dan kalimat sederhana yaitu dengan cara: peneliti menyusun kartu surat dan menyusun serta menyusun kartu huruf tersebut menjadi kosakata, kemudian meminta subjek untuk membacanya. Peneliti menyusun huruf timbul menjadi kosakata, dan meminta subjek untuk menutupnya mata, kemudian membimbingnya untuk merasakan huruf timbul dan membacanya. Peneliti menulis beberapa kalimat sederhana dan meminta subjek untuk membacanya. Selain itu peneliti menuliskan kosakata yang sulit dan jarang ditemui subjek, kemudian memintanya untuk membaca. Sesi ini diakhiri dengan pengulangan kembali materi yang telah dipelajari dan peneliti mengajukan pertanyaan.

Tahap Akhir (Tahap Dasar-2). Tahap terakhir dilakukan dengan pemberian tes kemampuan membaca pendahuluan seperti pada baseline-1. Ujian dilaksanakan selama 1 minggu selama 3 sesi pertemuan. Kegiatan baseline-2 ini bertujuan untuk mengetahui efektivitas metode multisensori dalam meningkatkan keterampilan membaca awal pada anak retardasi ringan dengan membandingkan hasil baseline-1.

\section{Teknik analisis data}

Teknik analisis data yang digunakan dalam penelitian ini adalah teknik analisis data statistik deskriptif. Dalam penelitian eksperimental dengan subjek tunggal, teknik analisis yang digunakan adalah statistik deskriptif sederhana (Myers \& Hansen, 2011). Pada penelitian ini digunakan grafik untuk menunjukkan perubahan data untuk setiap sesi dalam baseline dan intervensi dan menggunakan analisis dalam kondisi dan antar kondisi. Ada beberapa komponen yang dianalisis dalam kondisi tersebut yaitu panjang kondisi, arah tren, tingkat stabilitas, laju perubahan, jejak data, dan jangkauan. Sedangkan komponen analisis data antar kondisi meliputi perubahan variabel, perubahan arah dan pengaruh, perubahan level data, dan data overlap atau tumpang tindih (Sunanto, 2006).

\section{HASIL PENELITIAN}


Hasil keseluruhan dari baseline fase-

1, fase intervensi, dan fase baseline-2

disajikan dalam tabel 1 di bawah ini:

Tabel 1. Persentase Data Akumulasi Subjek yang Berhasil Mengikuti Tes Kemampuan Membaca Awal pada Fase Baseline-1, Fase Intervensi, dan Fase Baseline-2

\begin{tabular}{cccc}
\hline Target pelanggar & \multicolumn{3}{c}{ Persentase keberhasilan (\%) } \\
\hline Tes membaca awal & Dasar-1 (A1) & Intervensi (B) & baseline-2 (A2) \\
\cline { 2 - 4 } & 30 & 54.54 & 71.81 \\
& 32.72 & 52.72 & 85.45 \\
& 34.54 & 56.36 & 86.36 \\
& & 50.90 & \\
& & 65.45 & \\
\hline
\end{tabular}

Dari tabel persentase keberhasilan di atas dapat diketahui terjadi peningkatan skor yang diperoleh dari baseline-1 pertama yaitu $30 \%$ menjadi $34,54 \%$ pada baseline- 1 ketiga. Pada fase intervensi rata-rata juga meningkat, dari 54,54\% pada fase intervensi pertama menjadi $67,72 \%$ pada fase intervensi keenam. Fase baseline-2 juga mengalami peningkatan, dari $71,81 \%$ pada fase intervensi pertama menjadi $86,36 \%$ pada fase intervensi ketiga.

Hasil persentase keberhasilan subjek dalam mengambil soal tes dari baseline-1 hingga baseline-2 disajikan dalam grafik di gambar 1 sebagai berikut:

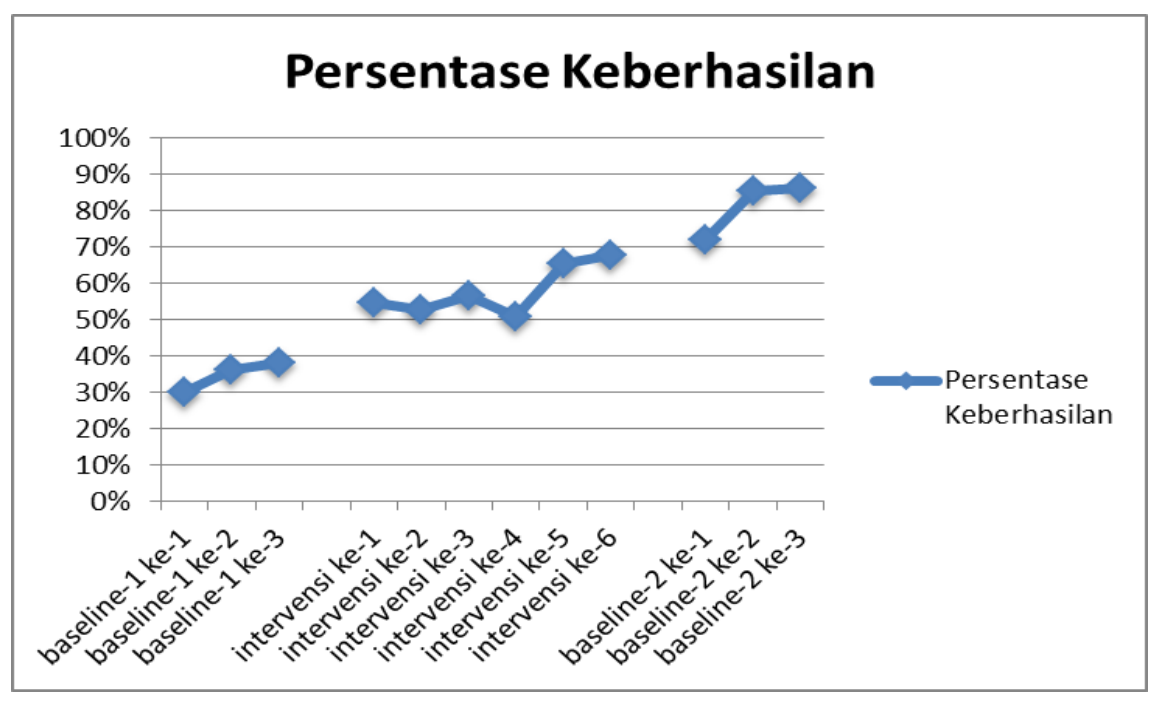

Gambar 1. Data Grafik Akumulasi Persentase Keberhasilan Subjek dalam Melakukan Tes Kemampuan Membaca Awal pada Fase Baseline-1, Fase Intervensi, dan Fase Baseline-2

Dari data di atas,Hal ini terlihat bahwa terdapat peningkatan nilai tes yang diperoleh subjek dalam mengerjakan soal tes keterampilan membaca. Pada fase baseline-1 dari 30\% menjadi 34,54\%, pada fase intervensi dari $54,54 \%$ menjadi $67,72 \%$, dan pada fase baseline-2 dari $71,81 \%$ menjadi $86,36 \%$. Lamanya waktu yang dibutuhkan subjek untuk mengerjakan soal tes kemampuan membaca awal dari fase 
baseline-1, fase intervensi, dan fase baseline-

2 ditampilkan pada tabel 2 sebagai berikut:

Tabel 2. Akumulasi Data Durasi Waktu pada Proses Tes Kemampuan Membaca Awal pada Fase Baseline-1, Fase Intervensi, dan Fase Baseline-2

\begin{tabular}{cccc}
\hline $\begin{array}{c}\text { Target } \\
\text { pelanggar }\end{array}$ & \multicolumn{3}{c}{ Durasi Waktu (menit) } \\
\hline Tes membaca & Dasar-1 (A1) & Intervensi (B) & Dasar-2 (A2) \\
awal & 25 & 23 & 13 \\
\cline { 2 - 4 } & 23 & 20 & 10 \\
& 25 & 27 & 10 \\
& 24 & \\
& & 18 & \\
& & 15 & \\
\hline
\end{tabular}

Dari tabel di atas terlihat bahwa subjek pada soal tes memiliki ketidakstabilan waktu pada fase baseline-1 yaitu 25 menit pada fase baseline-1 pertama, 23 menit pada fase baseline-1 kedua, dan 25 menit pada fase baseline-1. Pada fase intervensi berkurang dari 23 menit pada fase intervensi pertama menjadi 15 menit pada fase intervensi keenam. Fase baseline-2 juga mengalami penurunan waktu, dari 13 menit pada fase baseline- 2 pertama menjadi 10 menit pada fase baseline-2 ketiga.

Data durasi soal tes dari baseline-1 hingga baseline-2 juga disajikan dalam bentuk grafik di gambar 2 berikut ini:

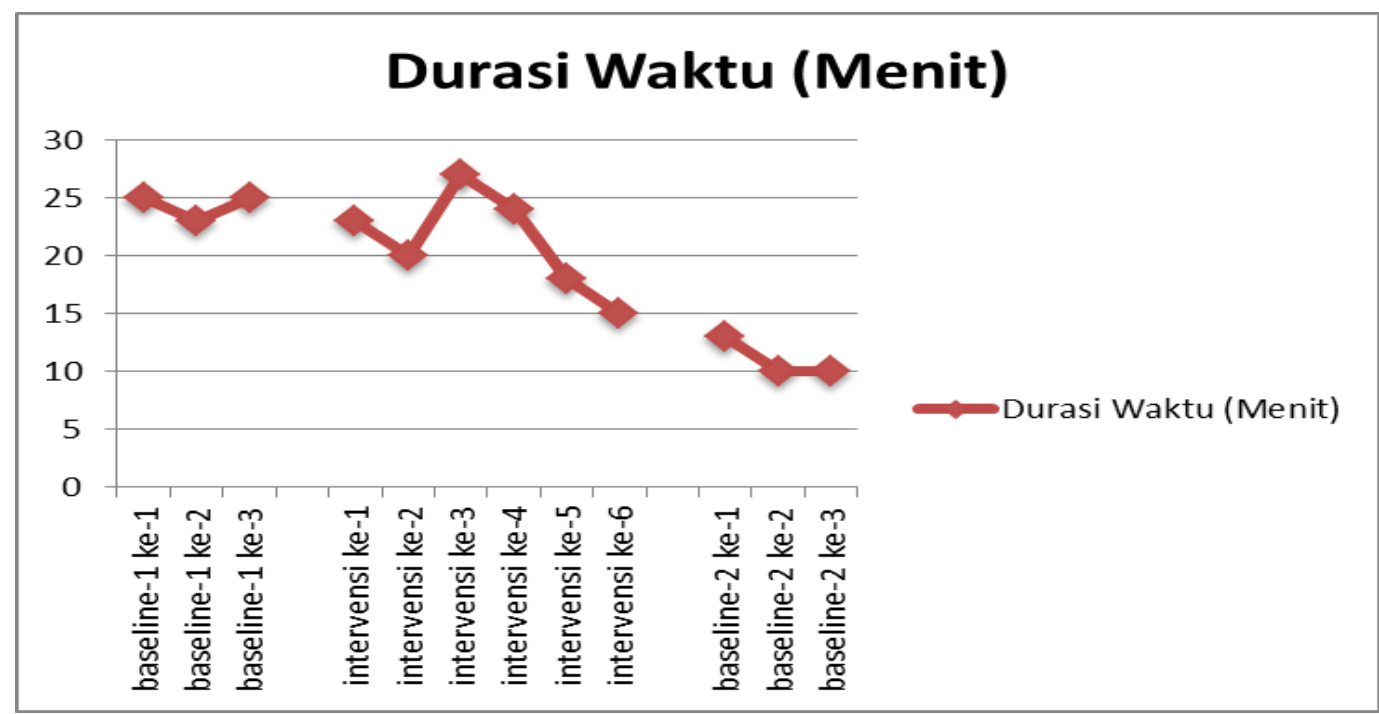

Gambar 2. Grafik Durasi Waktu Akumulasi Soal Tes Kemampuan Membaca Pendahuluan pada Fase Baseline-1, Fase Intervensi, dan Fase Baseline-2

Dari data durasi waktu, terlihat bahwa subjek mengerjakan soal tes kemampuan membaca awal pada tahap baseline-2. Setelah intervensi, terjadi penurunan waktu dari baseline-1, yakni dari 25 menit hingga 10 menit.

Selain data persentase keberhasilan yang diperoleh subjek, berikut adalah hasil analisis data dalam kondisi dan antar 
kondisi. Semua data analisis untuk kondisi tersebut disajikan dalam tabel 3 di bawah ini:

Tabel 3. Hasil Analisis Data Berdasarkan Kondisi

\begin{tabular}{|c|c|c|c|}
\hline Kondisi & Dasar-1 (A1) & Intervensi (B) & Dasar-2 (A2) \\
\hline Kondisi panjang & 3 & 6 & 3 \\
\hline Arah arah & $(+)$ & $1+1$ & $(+)$ \\
\hline Tren stabil & $\begin{array}{l}66,67 \% \\
\text { Stabil }\end{array}$ & Variabel & $100 \%$ \\
\hline Jejak data & & & \\
\hline $\begin{array}{c}\text { Tingkat stabilitas } \\
\text { dan jangkauan }\end{array}$ & $\begin{array}{c}30 \%-34,54 \% \\
\text { Stabil } \\
\end{array}$ & $\begin{array}{c}54,54 \%-67,72 \% \\
\text { Variabel }\end{array}$ & $\begin{array}{c}71,81 \%-86,36 \% \\
\text { Stabil } \\
\end{array}$ \\
\hline Perubahan level & $\begin{array}{l}34,54 \%-30 \% \\
\quad=4,54 \%\end{array}$ & $\begin{array}{c}67,72 \%-54,54 \% \\
=13,18 \%\end{array}$ & $\begin{array}{c}86,36 \%-71,81 \% \\
=14,55 \%\end{array}$ \\
\hline
\end{tabular}

Data di atas memperlihatkan adanya tren yang cenderung terus meningkat secara bertahap sejak baseline-1. Pada tingkat perubahan baseline-1 terjadi peningkatan dari $4,54 \%$ menjadi $13,18 \%$, dan dari $13,18 \%$ menjadi $14,55 \%$.

Semua analisis data antar kondisi disajikan dalam tabel 4 di bawah ini:

Tabel 4. Hasil Analisis Data Antar Kondisi

\begin{tabular}{|c|c|c|}
\hline Perbandingan kondisi & A1 - B & B - A2 \\
\hline $\begin{array}{c}\text { Jumlah variabel yang } \\
\text { diukur }\end{array}$ & 1 & 1 \\
\hline \multirow[t]{2}{*}{ Ubah arah dan efek } & $(+)$ & $(+)$ \\
\hline & Positif & Positif \\
\hline $\begin{array}{c}\text { Perubahan stabilitas } \\
\text { tren }\end{array}$ & Stabil terhadap variabel & Variabel menjadi stabil \\
\hline Perubahan level & $\begin{array}{c}54,54-34,54=20 \\
(+)\end{array}$ & $\begin{array}{c}71,81-67,72=4,09 \\
(+)\end{array}$ \\
\hline $\begin{array}{c}\text { Data yang tumpang } \\
\text { tindih }\end{array}$ & $0: 6 \times 100 \%=0 \%$ & $0: 3 \times 100 \%=0 \%$ \\
\hline
\end{tabular}

Dari data di atas dapat dilihat bahwa di dalam data tumpang tindih hasilnya $0 \%$. Hal ini menunjukkan bahwa tidak ada data yang tumpang tindih dari setiap tahapan.

\section{PEMBAHASAN}

Penelitian ini bertujuan untuk mengetahui pengaruh metode multisensori terhadap kemampuan membaca pada anak retardasi mental ringan. Berdasarkan hasil analisis yang telah dilakukan di atas menunjukkan bahwa metode multisensori efektif meningkatkan kemampuan membaca pada anak retardasi mental ringan kelas VI di SLB Bina Bangsa, Ngelom, Taman, Sidoarjo. Hal ini terlihat dari hasil data yang diperoleh dari fase baseline-1, fase intervensi, dan fase baseline-2 yang 
dianalisis dari dalam dan antar kondisi. Hasil nilai tes yang diperoleh subjek meningkat di setiap fase.

Hasil penelitian ini sejalan dengan Wardani, (1995) bahwa untuk dapat membaca permulaan, anak harus mampu menguasai beberapa hal diantaranya membedakan huruf, melafalkan bunyi huruf dan kata dengan benar. Dalam penelitian ini tujuan utamanya adalah untuk meningkatkan kemampuan membaca pada anak retardasi mental ringan yang masih kesulitan mengidentifikasi huruf " $L$ " dan " $R$ ", suku kata, kata, dan kalimat sederhana. Persentase rata-rata kemampuan membaca awal subjek atau tingkat rata-rata dari fase baseline-1 hingga baseline-2 meningkat dengan menerapkan metode multisensori.

Berdasarkan hasil analisis data diperoleh pada fase baseline-1 stabil ke atas, pada fase intervensi bervariasi atau tidak stabil, dan pada fase baseline-2 stabil ke atas. Perubahan level data analisis terutama persentase keberhasilan pada tes membaca awal menunjukkan bahwa antara fase baseline-1 dan fase intervensi (A1 - B) terdapat perubahan level data sebesar $(+20)$, dan pada kondisi antara fase intervensi dan fase baseline-2 (B - A2) didapatkan perubahan level data (+4.09). Hal ini menunjukkan bahwa antara kemampuan membaca awal subjek pada fase baseline-1 dengan fase intervensi mengalami peningkatan dengan penerapan metode multisensori, dan antara fase intervensi dan fase baseline-2 juga mengalami peningkatan. Namun demikian, peningkatan yang dihasilkan tidak sebanyak pada fase baseline-1 dengan intervensi.

Analisis antara kondisi tersebut sesuai dengan pendapat yang dikemukakan oleh Sunanto, (2006) yang menunjukkan besarnya suatu perlakuan, merupakan komponen penting untuk mengetahui ada tidaknya pengaruh intervensi yang diberikan terhadap variabel terikat, termasuk aspek stabilitas, perubahan level, dan ada atau tidaknya data yang tumpang tindih.

Hasil analisis data overlap atau data tumpang tindih antar kondisi dapat mempengaruhi perubahan antar kondisi berdasarkan adanya data yang sama antara data pembanding dengan data yang dibandingkan. Semakin banyak data yang sama atau tumpang tindih antara kedua kondisi tersebut, semakin kurang efektif intervensinya. Hal ini sejalan dengan Sunanto, (2006) bahwa semakin kecil persentase overlap maka semakin baik intervensi terhadap variabel yang diubah. Pada penelitian ini, hasil analisis data overlap yang dihasilkan pada fase baseline-1 dan fase intervensi (A1 -B) adalah $0 \%$, serta pada fase intervensi dan fase baseline- 2 juga $0 \%$. Hal ini menunjukkan bahwa tidak ada data yang tumpang tindih yang dihasilkan dari setiap tahapan dan metode intervensi yang diberikan berpengaruh positif.

Selain hasil analisis data persentase keberhasilan kondisi dan antar kondisi, juga dilakukan analisis durasi waktu untuk setiap tahapan. Lamanya waktu yang dibutuhkan subjek untuk menyelesaikan tes kemampuan membaca awal dari fase baseline-1, fase intervensi, dan fase baseline2 secara keseluruhan semakin berkurang. Hal ini menunjukkan bahwa intervensi yang diberikan berpengaruh baik terhadap kemampuan membaca awal subjek, karena waktu penyelesaian soal tes mengalami penurunan. Hal ini diperkuat dengan pendapat Pertiwi, (2016) bahwa semakin sedikit waktu yang dibutuhkan subjek untuk mengerjakan soal tes maka semakin efektif pula perlakuan yang diberikan.

Strategi atau cara untuk meningkatkan kemampuan membaca pada anak retardasi mental ringan, dapat juga dengan menerapkan metode P2r yang terbukti meningkatkan kemampuan membaca sejak dini pada anak retardasi 
mental ringan. Hal dibuktikan dengan hasil penelitian Sari, (2014) bahwa ada peningkatan setelah subjek diberikan perlakuan dengan menggunakan metode P2r.

Selain itu, penggunaan multimedia interaktif, pembelajaran cerdas membaca, juga efektif untuk meningkatkan kemampuan memulai membaca pada anak retardasi mental ringan. Hal ini sesuai dengan penelitian yang dilakukan oleh Sidiq \& Fauziah, (2012), bahwa kemampuan membaca awal subjek meningkat setelah diberikan intervensi multimedia cerdas membaca.

Selain itu, metode membaca dengan nyaring juga dapat meningkatkan keterampilan membaca pada anak retardasi mental ringan. Hal tersebut dibuktikan oleh Mahartika \& Dewantoro, (2017), dari hasil penelitiannya yang menunjukkan adanya pengaruh yang signifikan dari metode membaca nyaring terhadap kemampuan pemahaman yang dimiliki oleh subjek. Selain itu, pelatihan kesadaran persepsi visual juga dapat meningkatkan kemampuan pra membaca anak retardasi mental ringan. Hal ini sesuai dengan penelitian yang dilakukan oleh Juhanaini \& Susilawati (2009), hasil penelitian menunjukkan bahwa terdapat pengaruh positif terhadap kemampuan membaca subjek setelah diberikan perlakuan.

Kemampuan membaca subjek setelah diberikan perlakuan berupa metode multisensori menunjukkan peningkatan. Subjek telah mampu mengidentifikasi beberapa huruf yang sebelumnya tidak dapat diidentifikasi. Hal ini ditunjukkan dengan fakta bahwa subjek telah mampu mengidentifikasi huruf yang sebelumnya tidak dapat mengenali, serta mampu membaca kata atau kalimat sederhana yang jarang ditemui. Hal ini sejalan dengan penelitian yang dilakukan oleh Setyawati (2017) dengan hasil bahwa metode multisensori efektif dalam meningkatkan kemampuan membaca sejak dini pada anak retardasi mental ringan kelas II di SLB Yuketunis, Semarang.

Keterbatasan dalam penelitian ini antara lain, terkadang subjek merasa bosan dan mengantuk pada saat proses penelitian berlangsung yang mengakibatkan subjek tidak konsentrasi. Selain itu, penelitian ini dilakukan dirumah subjek, di mana kondisi lingkungan rumah subjek yang cukup ramai mengakibatkan perhatian subjek terbagi dengan kebisingan, dan membuat peneliti mengeraskan suaranya. Pemilihan waktu dan durasi waktu juga berkontribusi pada aktivitas anak. Tahap baseline I yang dilakukan pada pukul $11.00 \mathrm{WIB}$, membuat subjek mudah bosan dengan materi yang diberikan. Terlebih lagi durasi waktu yang diambil pada fase baseline-1 dan baseline- 2 pada setiap sesi dilakukan secara berturutturut sehingga subjek bosan dan malas mengerjakan soal tes yang diberikan.

\section{SIMPULAN DAN SARAN}

\section{Kesimpulan}

Berdasarkan hasil penelitian dan pembahasan dapat disimpulkan bahwa metode multisensori efektif dalam meningkatkan kemampuan membaca awal pada anak retardasi mental ringan kelas VI di SLB Bina Bangsa, Ngelom, Taman, Sidoarjo. Hal tersebut sesuai dengan hasil penelitian yang menunjukkan adanya peningkatan persentase keberhasilan tes keterampilan membaca pada setiap tahapan yaitu dari fase baseline-1, fase intervensi, dan fase baseline-2. Selain itu, hasil pengujian ini juga didukung oleh hasil data yang overlapping yaitu $0 \%$ hal ini sesuai dengan kriteria keberhasilan intervensi yang diberikan.

\section{Saran}

Bagi guru diharapkan lebih banyak memberikan pendampingan dan bimbingan 
individu kepada anak yang kemampuan membaca masih rendah sehingga kesulitan membaca anak dapat berkurang. Bagi orang tua diharapkan selalu mengulang materi pembelajaran yang telah dilakukan di sekolah agar daya ingat anak dapat meningkat, khususnya dalam materi pembelajaran membaca. Selain itu disarankan juga kepada peneliti selanjutnya agar menggunakan teknik analisis statistik inferensial.

\section{DAFTAR PUSTAKA}

Abdurrahman, M. (2009). Pendidikan untuk anak-anak dengan kesulitan belajar. Rineka Cipta.

Astuti, Y. C. (2013). Dukungan sosial dengan strategi coping pada ibu memiliki anak penyandang disabilitas (Studi korelasi ibu dengan anak penyandang disabilitas anak penyandang disabilitas YPLB Cipaganti Bandung) [Skripsi, Universitas Pendidikan Indonesia]. Repository Universitas Pendidikan Indonesia. http://repository.upi.edu/3885/

Chodijah, M. (2014). Model bimbingan kolaboratif untuk meningkatkan kemampuan akademik anak yang mengalami kesulitan belajar di Sekolah Dasar Inklusi [Skripsi, Universitas Pendidikan Indonesia]. Universitas Pendidikan Indonesia.

Diyah, A. D. (2014). Peningkatan kemampuan membaca permulaan dengan menggunakan media buku popup pada anak tunagrahita kategori ringan kelas IV di SLB Dharma Rena Ring Putra 1 Yogyakarta [Skripsi, Universitas Negeri Yogyakarta]. https://eprints.uny.ac.id/42689/

Juhanaini, J., \& Susilawati, E. (2009). Pengaruh latihan kesadaran persepsi visual terhadap kemampuan membaca permulaan pada anak tunagrahita ringan di SLB Kasih Ibu dan SLB YJS III Kabupaten Bandung. Jurnal Asesmen Dan Intervensi Anak Berkebutuhan Khusus, 8(1), 49-53. https://ejournal.upi.edu/index.php/ja ssi/article/view/3897

Komalasari, M. D. (2013). Metode multisensori untuk meningkatkan kemampuan membaca pada siswa disleksia di sekolah dasar. Jurnal Psikologi Pendidikan, 5(3), 97-110.

Kusumaningtyas, D. (2015). Efektivitas metode multisensori terhadap kemampuan menulis anak penyandang kesulitan belajar menulis di kelas II SD Muhammadiyah Demangan. Yogyakarta [Skripsi, Universitas Negeri Yogyakarta]. http://eprints.uny.ac.id/34511/

Lestari, I. (2014). Dysfun course (Kursus membaca dan menulis pertama di indonesia bagi anak-anak yang mengidap disleksia). In Pekan Ilmiah Mahasiswa Nasional Program Kreativitas Mahasiswa Kewirausahaan 2014.

Mahartika, A. S., \& Dewantoro, D. A. (2017). Meningkatkan kemampuan membaca pemahaman anak tunagrahita ringan dengan menggunakan metode reading aloud. Jurnal ORTOPEDAGOGIA, 3(2), 123-126. https://doi.org/10.17977/um031v3i2 2017p123

Maslim. (2013). Diagnosis gangguan jiwa: Rujukan ringkas dari PPDGJ - III Dan $D S M$ - 5. PT Nuh Jaya.

Myers, A., \& Hansen, C. H. (2011). Experimental psychology. Cengage 
Learning.

https://books.google.co.id/books?id= AZgFmMqpWTUC

Pertiwi, E. N. (2016). Efektivitas penerapan metode multisensori terhadap kemampuan membaca permulaan tulisan awas pada anak tunanetra low vision kelas I SDLB Di DLB A Yaketunis Yogyakarta [Skripsi, Universitas Negeri Yogyakarta]. Universitas Negeri Yogyakarta.

Santosa, S. (2012). Pengajaran membaca di Sekolah Dasar. Bumi Aksara.

Sari, A. M. (2014). Meningkatkan kemampuan membaca kata pada anak tunagrahita ringan melalui metode P2R. Jurnal Penelitian Pendidikan Khusus, 3(1), 48-61.

http://ejournal.unp.ac.id/index.php/ju pekhu/article/view/3047

Setyawati, S. (2017). Peran remidial teaching dalam meningkatkan keterampilan membaca pada anak tunagrahita ringan. Jurnal Psikologi, 4(1), 19-33.
Sidiq, Z., \& Fauziah, P. (2012). Penggunaan multimedia interaktif untuk pembelajaran cerdas membaca dalam meningkatkan kemampuan membaca awal pada anak dengan disabilitas ringan. Jurnal Psikologi Pendidikan, 11(1), 1-9.

Slamet, A., \& Vismaia, S. (2003). Membaca teori dan praktek. Mutiara.

Sunanto, J. (2006). Riset dengan satu subjek. UPI Press.

Tarigan, H. (2008). Membaca sebagai keterampilan bahasa. Luar Angkasa.

Wardani, A. K. (1995). Pengajaran bahasa indonesia bagi anak berkesulitan belajar. Departemen Pendidikan Dan Kebudayaan Direktorat Dirjen Pendidikan Tinggi Proyek Pendidikan Guru. 